\title{
Analisis Kontribusi Pajak Mobil LCGC Terhadap Penerimaan Pajak Kendaraan Bermotor Sumatera Barat
}

\author{
Putri Intan Permata Sari \\ Elfiswandi \\ Pascasarjana Universitas Andalas \\ Jalan Universitas Andalas, Limau Manis, Pauh, Kota Padang, Indonesia, 25163 \\ putriintanpermatasari82@gmail.com
}

\begin{abstract}
This research aims to determine the contribution of Low Cost Green Car vehicle tax to the tax revenue of West Sumatera Province. The sample is purposively selected from Low Cost Green Car based on the type, the registration and the payment to the Office of Regional Finance of West Sumatra Province from 2013 to June 2016. The data was obtained from interviews on targets and realization of the tax vehicles revenue in West Sumatra. The method of analysis used in this research was the descriptive analysis method. The results showed that a high contribution of Low Cost Green Car toward the tax vehicles revenue. In addition, the Low Cost Green Car tax are made part of minibus or station wagon at the local revenue.
\end{abstract}

Keywords: Contribution, Low Cost Green Car, Vehicle Tax

\begin{abstract}
Abstrak
Penelitian ini bertujuan untuk mengetahui kontribusi pajak kendaraan bermotor jenis Low Cost Green Car terhadap pendapatan pajak kendaraan bermotor di Sumatera Barat. Sampel yang digunakan adalah Low Cost Green Car berdasarkan jenis, terdaftar dan juga terbayar di kantor manajemen keuangan Provinsi Sumatera Barat pada periode 2013 hingga Juni 2016. Penentuan sampel menggunakan metode purposive sampling. Sumber data penelitian ini diperoleh dari wawancara tentang target serta realisasi pendapatan pajak kendaraan bermotor di Sumatera Barat. Metode analisis yang digunakan dalam penelitian ini adalah metode analisis deskriptif. Hasil analisis menunjukkan bahwa kontribusi pajak Low Cost Green Car terhadap pendapatan kendaraan pajak adalah tinggi. Dengan catatan, jenis pajak Low Cost Green Car dalam realisasi pendapatan asli daerah dimasukkan ke dalam jenis pajak untuk kendaraan jenis minibus atau st wagon.
\end{abstract}

Kata Kunci: Kontribusi, Low Cost Green Car, Pajak Kendaraan Bermotor

\section{PENDAHULUAN}

Pembangunan daerah adalah bagian integral dari upaya pembangunan nasional dalam memberikan pelayanan dan meningkatkan kesejahteraan masyarakat. Dengan adanya otonomi daerah melalui Undang-Undang Nomor 23 Tahun 2014, urusan pemerintah yang mulanya bersifat sentralisasi berubah menjadi desentralisasi. Dalam hal ini, pemerintah daerah mengatur sendiri daerahnya terutama dalam bidang perpajakan. Pajak merupakan sumber pendapatan yang mempunyai peranan penting dalam pembangunan suatu daerah yang bersifat autonom (Zuraida, 2013). Salah satu pajak yang dipungut oleh Pemerintah Daerah adalah Pajak Kendaraan Bermotor (PKB) melalui kepemilikan kendaraan bermotor.

Seiring meningkatnya perekonomian masyarakat Sumatera Barat, kebutuhan masyarakat akan transportasi darat semakin meningkat salah satunya kendaraan roda empat. Sistem transportasi utama di Kota Padang saat ini adalah angkutan umum. Namun dalam penggunaannya, angkutan umum ini sering melanggar lalu lintas, berhenti di sembarang tempat, dan mengebut. Akibatnya masyarakat merasa tidak nyaman, tidak memiliki kepastian waktu perjalanan, tingkat keselamatan yang rendah, dan keamanannya tidak terjamin. Hal inilah yang menyebabkan 
masyarakat lebih banyak beralih pada kendaraan pribadi. Hal ini dapat kita lihat pada Gambar 1 yang menunjukkan minat masyarakat untuk memiliki kendaraan pribadi sangat tinggi.

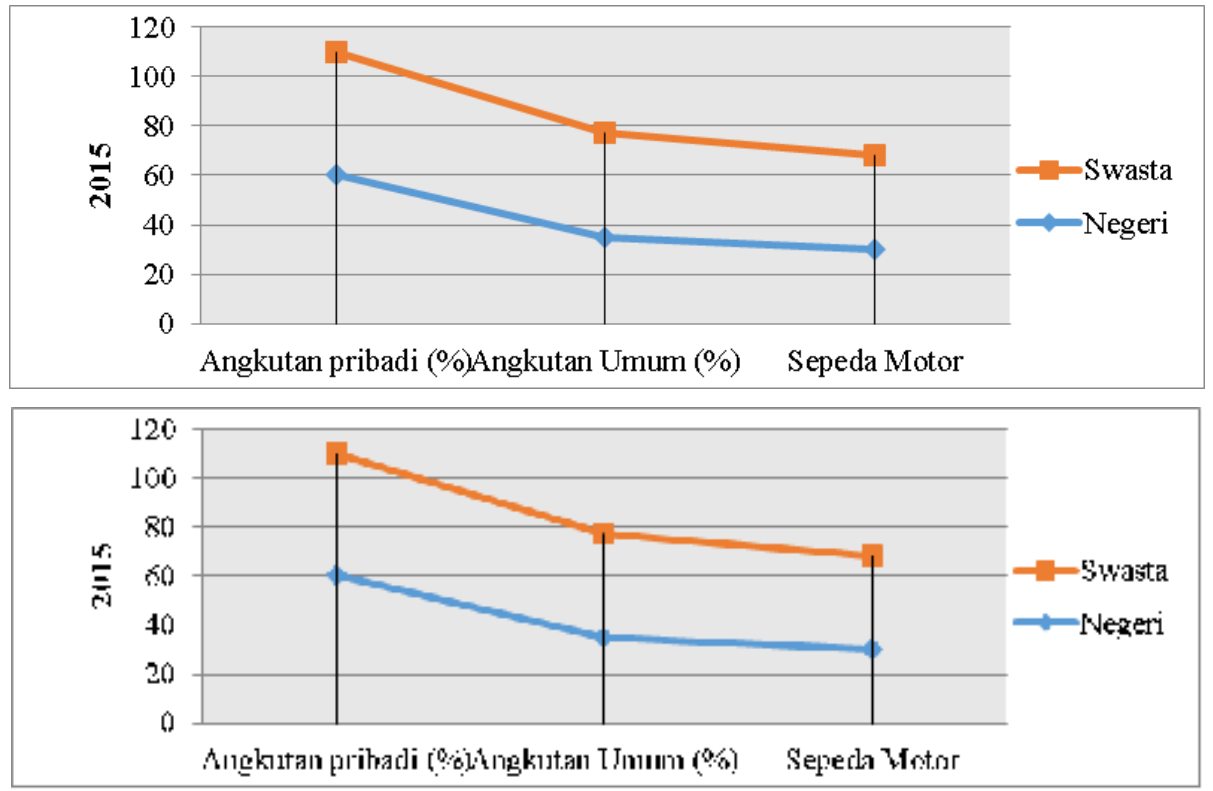

Gambar 1. Grafik Penggunaan Moda di Kota 2015 (Sumber: Pratama, 2015)

Pemerintah telah menetapkan program Pengembangan Produksi Kendaraan Bermotor Roda Empat Hemat Energi dan Harga Terjangkau (PPKB) atau lebih dikenal dengan Low Cost Green Car (LCGC) melalui Peraturan Menteri Perindustrian Nomor 33/M-IND/PER/7/2013. Kebijakan ini akan mendorong minat dan daya beli masyarakat serta memberikan kemudahan bagi masyarakat lapisan ekonomi kelas bawah untuk memiliki kendaraan pribadi dengan harga yang lebih terjangkau. Istiyanto dan Nugroho (2017) menyatakan bahwa harga mobil LCGC yang lebih murah memiliki pengaruh signifikan dalam keputusan pembelian mobil LCGC dan sesuai dengan kualitan produknya.

Tabel 1. Realisasi dan Target Penerimaan Pajak Kendaraan Bermotor di Sumatera Barat Tahun 2012 s.d. Juni 2016

\begin{tabular}{|c|c|c|c|c|}
\hline \multirow{2}{*}{ Tahun } & \multicolumn{4}{|c|}{ Penerimaan Pajak Kend araan Bemotor } \\
\hline & & Target & & Realisasi \\
\hline 2012 & $\mathrm{Rp}$ & $380,877,680,000.00$ & $\mathrm{Rp}$ & $378,864,221,217.00$ \\
\hline 2013 & $\mathrm{Rp}$ & $406,112,787,000.00$ & $\mathrm{Rp}$ & $415,054,017,910.00$ \\
\hline 2014 & $\mathrm{Rp}$ & $426,935,043,000.00$ & $\mathrm{Rp}$ & $461,713,837,205.00$ \\
\hline 2015 & $\mathrm{Rp}$ & $458,000,000,000.00$ & $\mathrm{Rp}$ & $487,742,104,641.00$ \\
\hline 2016 (Januari s.d. Juni) & $R p$ & $470,400,000,000.00$ & $R p$ & $269,612,998,025.00$ \\
\hline
\end{tabular}

Sumber: DPKD Provinsi Sumatera Barat

Dari Tabel 1, dapat dilihat bahwa sejak diberlakukannya mobil LCGC pada tahun 2013, realisasi penerimaan PKB di Provinsi Sumatera Barat semakin meningkat dan selalu melebihi target. Namun, pada tahun 2012 sebelum berlakunya mobil LCGC, realisasi penerimaan PKB tidak mencapai target yang diharapkan. Semakin tinggi penerimaan PKB maka semakin tinggi penerimaan pajak daerahya. Hal ini diperkuat oleh penelitian yang dilakukan oleh Winarso (2015), Sari (2016), Rompis et al. (2015) yang mengatakan bahwa penerimaan PKB memberikan kontribusi yang cukup besar terhadap Pajak Daerah sehingga akan mempengaruhi jumlah Pendapatan Asli Daerah.

Penelitian ini mengacu kepada penelitian yang dilakukan oleh Male (2015) yang menyatakan bahwa jumlah mobil tipe LCGC ini mengalami pertumbuhan yang sangat pesat dalam periode 2013 hingga 2015. Hal ini menunjukkan bahwa produk LCGC menjadi salah satu yang diminati oleh masyarakat. Hal ini diperkuat dengan penelitian Erdiana dan Sutopo (2015) yang menyebutkan bahwa penjualan mobil LCGC khususnya mobil dengan merek Honda di Indonesia 
mengalami peningkatan. Pada tahun 2011, penjualan mobil Honda sebesar 45.416 unit, sedangkan untuk tahun 2012 dan 2013 penjualan masing-masing sebesar 69.320 dan 90.878 unit dengan peningkatan sebesar 11,63\% pada tahun 2012 dan 10,48\% pada tahun 2013. Hal ini akan membuat keberadaan mobil-mobil semakin banyak ditemukan di jalan raya sehingga secara tidak langsung akan memberikan peluang kepada pemerintah untuk mengoptimalkan Pendapatan Asli Daerah (PAD) melalui sektor PKB. Kantale (2016) mengatakan bahwa mobil jenis LCGC merupakan salah satu yang berpotensi mengumpulkan penerimaan PKB di Sulawesi Utara. Perbedaan penelitian ini dengan penelitian yang dilakukan oleh Male (2015) adalah objek penelitian yang dilakukan di Provinsi Sumatera Barat dengan rentang waktu dari 2013 hingga Juni 2016. Selain itu, penelitian ini tidak membahas mengenai efektivitas PKB. Tujuan dari penelitian ini adalah untuk mengetahui penerimaan PKB sebelum dan sesudah berlakunya LCGC serta mengetahui besarnya kontribusi yang diperoleh dari pajak mobil LCGC di Provinsi Sumatera Barat.

\section{METODE}

\section{Jenis Penelitian}

Penelitian ini merupakan penelitian kuantitatif yang menggambarkan potensi mobil tipe LCGC sebagai salah satu penerimaan PKB di Sumatera Barat. Penelitian ini menggunakan dua jenis data yaitu data primer dan data sekunder. Data primer yang digunakan dalam penelitian ini berupa hasil wawancara dengan salah seorang Kasi di Bidang Pajak Daerah DPKD Provinsi Sumatera Barat, sedangkan data sekunder dalam penelitian ini berupa jenis dan jumlah penerimaan pajak mobil LCGC di Provinsi Sumatera Barat.

\section{Metode Analisis Data}

Penelitian ini menggunakan metode analisis data secara deskriptif kuantitatif. Pengolahan data dalam penelitian ini mengacu pada penelitian yang dilakukan oleh Male (2015). Potensi pajak kendaraan jenis LCGC dapat diukur dengan rumus:

$$
\text { Potensi Mobil LCGC }=\frac{\text { Total Mobil LCGC yang Terdaftar }}{\text { Total Mobil terdaftar }}
$$

Setelah mengetahui potensi dari kendaraan LCGC, selanjutnya menghitung berapa besar kontribusi pajak mobil jenis LCGC terhadap PKB dengan rumus:

Kontribusi Pajak LCGC = Pajak Terutang Mobil LCGC x Jumlah Kendaraan LCGC

Pajak Terutang = Tarif Pajak $\mathrm{x}$ Dasar Pengenaan Pajak

Dasar Pengenaan Pajak $=$ NJKB x Bobot Kendaraan Bermotor

Selanjutnya, untuk melihat perilaku kontribusi PKB mobil jenis LCGC terhadap PKB di Sumatera Barat dalam periode 2013 sampai dengan Juni 2016 digunakan rumus:

$$
\mathrm{Y}=\frac{\text { PKB Tipe LCGC }}{\text { Total PKB }} \times 100 \%
$$

Keterangan:

1. Y merupakan hasil persentase kontribusi PKB jenis LCGC terhadap PKB pada masingmasing tahun

2. PKB tipe LCGC merupakan pajak yang diperleh dari mobil tipe LCGC

3. Total PKB adalah jumlah pendapatan dari PKB

\section{Analisis Korelasi}

Penelitian ini juga akan melihat bagaimana hubungan antara pajak LCGC dengan penerimaan PKB melalui analisis korelasi. Analisis korelasi yang digunakan dalam penelitian ini adalah pearson product moment. Menurut Sujarweni (2015), analisisi korelasi pearson product moment digunakan untuk mencari hubungan antara dua variabel pada data yang berbentuk interval atau rasio. Besarnya hubungan korelasi antar variabel dalam penelitian ini dapat dilihat pada nilai sig dengan berpedoman pada ketentuan pada Tabel 2 berikut ini. 
Tabel 2. Pedoman untuk Memberikan Interpretasi Koefisien Korelasi

\begin{tabular}{cc}
\hline Interval Koefisien $($ Sig) & Tingkat Hubungan \\
\hline $0,00-0,199$ & Sangat Lemah \\
$0,20-0,399$ & Lemah \\
$0,40-0,599$ & Sedang \\
$0,60-0,799$ & Kuat \\
$0,80-1,000$ & Sangat Kuat \\
\hline
\end{tabular}

Sumber: Sugiyono (2016)

\section{HASIL DAN PEMBAHASAN}

Persebaran Kendaraan Bermotor di Provinsi Sumatera Barat

Gambar 2 menunjukkan bahwa dari tahun 2012 sampai dengan Juni 2016, jumlah persebaran kendaraan bermotor di Sumatera Barat didominasi oleh Kota Padang dengan jumlah berkisar 400.000 setiap tahunnya. Wilayah tertinggi berikutnya adalah Kota Bukittinggi dan Kota Payakumbuh dengan jumlah berkisar antara 50.000 sampai dengan 100.000. Sebaliknya, dua wilayah dengan jumlah kendaraan bermotor terendah adalah kota Sawahlunto dengan jumlah kendaraan bermotornya berkisar 14.000 dan Solok Selatan dengan jumlah kendaraan bermotor berkisar 15.000 .

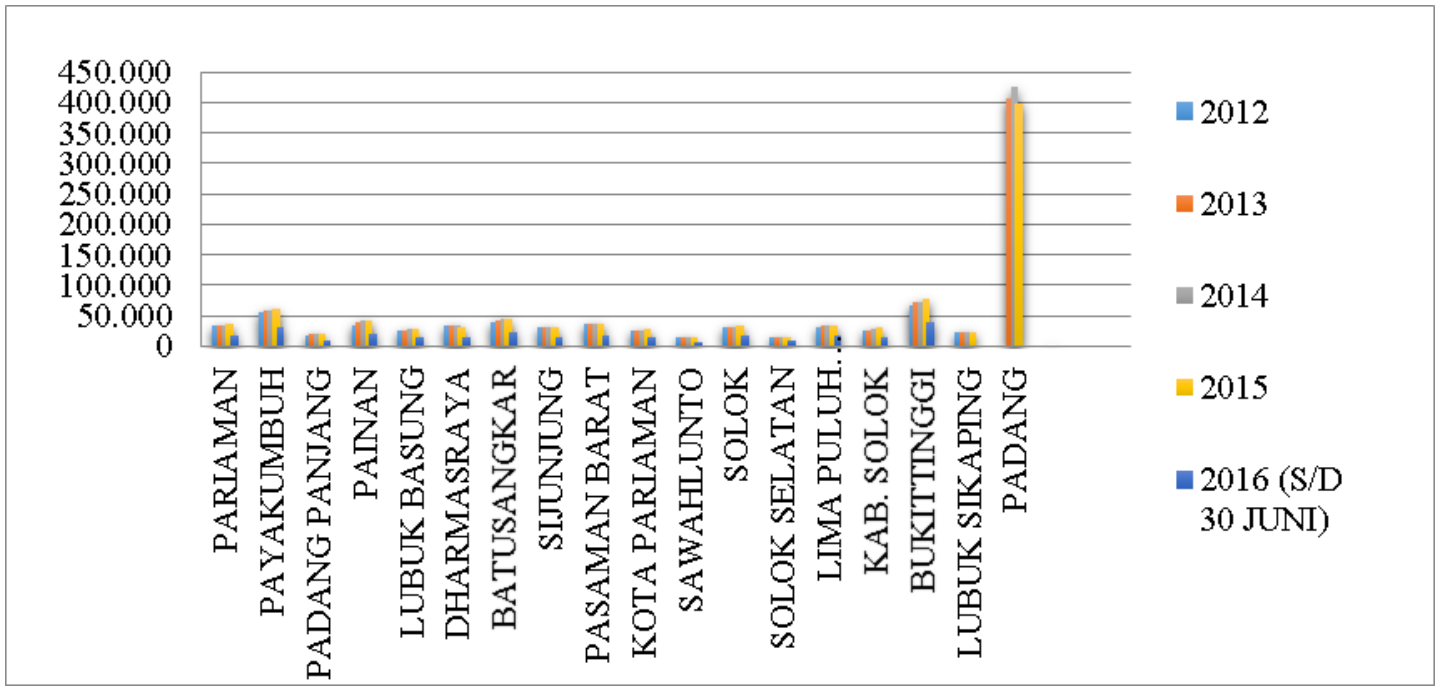

Gambar 2. Data Persebaran Kendaraan Bermotor Provinsi Sumatera Barat

\section{Peredaran dan Perbandingan Mobil Tipe Low Cost Green Car yang Terdaftar di Sumatera Barat}

Sajian perbandingan mobil jenis LCGC dengan kendaraan roda empat yang terdaftar dan terbayarkan di kantor DPKD Provinsi Sumatera Barat tahun 2013 sampai dengan Juni 2016, dapat dilihat pada Tabel 3 .

Tabel 3. Perbandingan Kendaraan tipe LCGC dengan kendaraan roda empat yang terdaftar dan terbayarkan

\begin{tabular}{cccc}
\hline Tahun & $\begin{array}{c}\text { Jumlah Kendaraan LCGC } \\
\text { Terdaftar dan Terbayarkan } \\
\text { (unit) }\end{array}$ & $\begin{array}{c}\text { Total Kendaraan Roda Empat } \\
\text { Terdaftar dan Terbayarkan } \\
\text { (unit) }\end{array}$ & $\begin{array}{c}\text { Persentase Potensi } \\
\text { Kendaraan LCGC } \\
(\%)\end{array}$ \\
\hline 2013 & 699 & 212.599 & 0,33 \\
2014 & 3.014 & 224.968 & 1,34 \\
2015 & 5.579 & 230.390 & 2,42 \\
Juni 2016 & 3.681 & 133.374 & 2,76 \\
\hline
\end{tabular}


Jumlah mobil tipe LCGC dari tahun 2013 sampai Juni 2016 sebesar 12.973 unit dengan rincian pada tahun 2013 jumlah mobil LCGC adalah 699 unit, pada tahun 2014 sebesar 3.014 unit, pada tahun 2015 adalah 5.579, dan pada tahun 2016 sebesar 3.681 unit. Mobil LCGC ini didominasi oleh tiga merk yaitu Toyota Agya, Honda Brio, dan Daihatsu Ayla. Pada tahun 2013 sebagai awal peluncuran mobil LCGC ini sampai dengan tahun 2014, jumlah mobil LCGC ini mengalami peningkatan yang cukup signifikan. Hal ini membuktikan bahwa peminat mobil LCGC ini semakin bertambah.

Pada tahun 2013 persentase jumlah mobil LCGC terhadap jumlah kendaraan roda empat sebesar $0,33 \%$. Pada tahun 2014 mengalami peningkatan menjadi $1,34 \%$, begitupun pada tahun 2015 dan tahun 2016 yang meningkat menjadi 2,42\% dan 2,76\%. Hal ini semakin memperlihatkan bahwa minat masyarakat Provinsi Sumatera Barat terhadap mobil LCGC kian meningkat.

\section{Analisis Kontribusi Pajak Kendaraan Bermotor Mobil Tipe Low Cost Green Car (LCGC) di Sumatera Barat}

Kontribusi dari PKB terhadap pajak daerah Provinsi Sumatera Barat dari tahun 2012 sampai dengan Juni 2016 dapat kita lihat pada Tabel 4.

Tabel 4. Kontribusi Pajak Kendaraan Bermotor terhadap Pajak Daerah

\begin{tabular}{cccc}
\hline Tahun & Pajak Kendaraan Bermotor $(\mathrm{Rp})$ & Pajak Daerah $(\mathrm{Rp})$ & Persentase $(\%)$ \\
\hline 2012 & 378.864 .221 .217 & 994.570 .032 .108 & 38,09 \\
2013 & 415.054 .017 .910 & 1.085 .164 .285 .343 & 38,25 \\
2014 & 461.713 .837 .205 & 1.354 .541 .147 .330 & 34,09 \\
2015 & 487.742 .104 .641 & 1.445 .611 .641 .469 & 33,74 \\
Jun-16 & 269.612 .998 .025 & 702.930 .567 .291 & 38,36 \\
\hline
\end{tabular}

Pada tahun 2012 kontribusi PKB terhadap Pajak Daerah sebesar 38,09\%. Pada tahun 2013 sedikit mengalami peningkatan sebesar 38,25\%, sedangkan pada tahun 2014 dan 2015 mengalami penurunan sebesar 34,09\% dan 33,74\%. Pada tahun 2016 mengalami peningkatan sebesar 38,36\%. Hal ini disebabkan penerimaan PKB pada tahun 2016 memiliki peranan yang cukup besar terhadap pendapatan daerah.

Sajian realisasi penerimaan pajak mobil LCGC, kontribusi pajak mobil LCGC terhadap pajak mobil jenis minibus/st. wagon, dan kontribusi pajak mobil LCGC terhadap PKB dapat dilihat pada Tabel 5 .

Tabel 5. Realisasi dan Kontribusi Pajak Kendaraan Bermotor 2013 s.d. Juni 2016

\begin{tabular}{|c|c|c|c|c|c|c|}
\hline \multirow{2}{*}{ Tahun } & \multicolumn{3}{|c|}{ Realisasi Penerimaan } & \multicolumn{3}{|c|}{ Kontribusi } \\
\hline & $\begin{array}{l}\text { Pajak Mobil Tipe } \\
\text { LCGC (Rp) }\end{array}$ & $\begin{array}{l}\text { Pajak Mobil Jenis } \\
\text { St.Wagon/ } \\
\text { Minibus (Rp) }\end{array}$ & $\begin{array}{c}\text { Pajak Kendaraan } \\
\text { Bermotor } \\
\text { Provinsi } \\
\text { Sumatera Barat } \\
\text { (Rp) }\end{array}$ & $\begin{array}{c}\text { Pajak } \\
\text { Mobil Tipe } \\
\text { LCGC } \\
\text { Terhadap } \\
\text { Pajak } \\
\text { Mobil Jenis } \\
\text { St.Wagon/ } \\
\text { Minibus } \\
(\%)\end{array}$ & $\begin{array}{c}\text { Pajak } \\
\text { Mobil } \\
\text { Tipe } \\
\text { LCGC } \\
\text { Terhadap } \\
\text { Pajak } \\
\text { Kendaraa } \\
\text { n } \\
\text { Bermotor } \\
(\%)\end{array}$ & $\begin{array}{c}\text { Pajak } \\
\text { Mobil Jenis } \\
\text { St.Wagon/ } \\
\text { Minibus } \\
\text { Terhadap } \\
\text { Pajak } \\
\text { Kendaraan } \\
\text { Bermotor } \\
(\%)\end{array}$ \\
\hline 2013 & 1.010 .265 .000 & 141.940 .252 .750 & 415.054 .017 .910 & 0,71 & 0,24 & 34,20 \\
\hline 2014 & 4.037 .430 .000 & 166.151 .874 .450 & 461.713 .837 .205 & 2,43 & 0,87 & 35,99 \\
\hline 2015 & 7.380 .270 .000 & 185.696 .492 .225 & 487.742 .104 .641 & 3,97 & 1,51 & 38,07 \\
\hline 2016 & 4.825 .710 .000 & 111.524 .906 .050 & 269.612 .998 .025 & 4,33 & 1,79 & 41,36 \\
\hline
\end{tabular}


Pada tahun 2013, kendaraan jenis LCGC memberikan sumbangan pendapatan PKB sebesar Rp 1.010.265.000 dari total penerimaan PKB jenis Station Wagon/Minibus sebesar Rp 141.940.252.750 atau dengan persentase kontribusi sebesar 0,71\%. Di tahun 2014 atau tahun kedua setelah peluncuran mobil-mobil LCGC, penerimaan pajak kendaraan mobil tipe LCGC menyumbang pendapatan PKB sebesar Rp 4.037.430.000 dari total penerimaan PKB Jenis Station Wagon/Minibus yang berjumlah sebesar Rp 166.151.874.450 atau dengan persentase kontribusi yang naik menjadi $2,43 \%$. Untuk tahun 2015, penerimaan pajak kendaraan mobil tipe LCGC menyumbang pendapatan PKB sebesar Rp 7.380.270.000 dari total penerimaan PKB jenis Station Wagon/Minibus yang berjumlah sebesar Rp 185.696.492.225 atau dengan persentase kontribusi juga mengalami peningkatan sebesar 3,97\%. Pada tahun 2016, berdasarkan data yang didapatkan sampai dengan bulan Juni, penerimaan pajak kendaraan mobil tipe LCGC telah menyumbang pendapatan PKB sebesar Rp 4.825.710.000 dari total penerimaan PKB jenis Station Wagon/ Minibus sebesar Rp 111.524.906.050 atau dengan persentase kontribusi yang sementara berada diangka $4,33 \%$.

\section{Hasil Analisis Korelasi}

Penelitian ini melihat hubungan antara pajak mobil jenis LCGC dengan penerimaan PKB setelah melihat seberapa besar kontribusi pajak mobil jenis LCGC terhadap penerimaan PKB. Hubungan antara pajak mobil jenis LCGC dengan penerimaan PKB dianalisis menggunakan analisis korelasi pearson yang dapat dilihat pada Tabel 6.

Tabel 6. Hasil Analisis Korelasi Pajak Mobil LCGC dengan Pajak Kendaraan Bermotor

\section{Correlations}

\begin{tabular}{llr|r} 
& & $\begin{array}{c}\text { Pajak Mobil } \\
\text { LCGC }\end{array}$ & $\begin{array}{c}\text { Pajak } \\
\text { Kendaraan } \\
\text { Bermotor }\end{array}$ \\
\hline Pajak Mobil LCGC & Pearson Correlation & 1 & .177 \\
\cline { 2 - 4 } & Sig. (2-tailed) & & .823 \\
\cline { 2 - 4 } & $\mathrm{N}$ & 4 & 4 \\
\hline $\begin{array}{l}\text { Pajak Kendaraan } \\
\text { Bermotor }\end{array}$ & Pearson Correlation & .177 & 1 \\
\cline { 2 - 4 } & Sig. (2-tailed) & .823 & \\
\hline $\mathrm{N}$ & 4 & 4 \\
\hline
\end{tabular}

Hasil analisis korelasi memiliki nilai sig sebesar 0,823 . Hal ini menunjukkan bahwa kontribusi dari pajak mobil LCGC memiliki hubungan yang sangat kuat terhadap PKB di Provinsi Sumatera Barat. Semakin tinggi penerimaan pajak mobil LCGC, maka akan semakin tinggi penerimaan PKB di Provinsi Sumatera Barat.

\section{Kendala dan Upaya Peningkatan Penerimaan Pajak Kendaraan Bermotor}

Berdasarkan hasil wawancara dengan salah seorang Kasi di Bidang Pajak Daerah Provinsi Sumatera Barat, Nina Nadjmir ditemukan bahwa ada beberapa kendala yang sering dihadapi oleh Dinas Pengelolaan Keuangan Daerah di Provinsi Sumatera Barat mengenai pemungutan PKB yang pada umumnya juga terjadi di berbagai Provinsi di seluruh Indonesia. Kendala tersebut berupa:

1. Kurangnya kesadaran dari masyarakat untuk membayar pajak kendaraan.

2. Kurangnya pelayanan yang mendukung kenyamanan para wajib pajak dalam aktivitas pembayaran PKB.

3. Sistem Samsat dan DPKD Provinsi Sumbar belum terintegrasi satu sama lain.

4. Kendaraan roda empat yang tergolong minibus/st. wagon tidak dirinci berdasarkan jenisnya seperti MPV dan LCGC.

5. Lemahnya penegakan hukum terhadap kepatuhan dalam membayar pajak.

\section{SIMPULAN DAN SARAN Simpulan}

Berdasarkan hasil analisis data dan pembahasan maka dapat diperoleh kesimpulan sebagai berikut: (1) Jumlah kendaraan setelah diberlakukannya mobil LCGC di Provinsi Sumatera Barat mengalami peningkatan sehingga dapat meningkatkan penerimaan PKB, (2) Mobil jenis LCGC memberikan kontribusi bagi penerimaan PKB berdasarkan realisasi penerimaan pendapa- 
tan asli daerah Provinsi Sumatera Barat dari sektor PKB jenis golongan Minibus/St.Wagon, (3) Penerimaan Pajak Mobil LCGC memiliki hubungan yang sangat kuat terhadap penerimaan PKB di Provinsi Sumatera Barat.

\section{Saran}

Saran yang dapat diberikan oleh peneliti adalah sebaiknya untuk mobil-mobil tipe LCGC dibuatkan standar tersendiri untuk penggolongan jenis kendaraan oleh Dinas Pengelolaan Keuangan Daerah karena ketentuan produksi tipe LCGC telah diatur oleh pemerintah. Bagi peneliti selanjutnya, evaluasi atas hasil penelitian ini juga harus mempertimbangkan keterbatasan yang mungkin mempengaruhi hasil penelitian, diantaranya adalah:

1. Data sekunder yang digunakan dalam penelitian ini sangat terbatas, sehingga diharapkan pada peneliti selanjutnya dapat menggunakan data sekunder yang lebih optimal.

2. Penelitian ini tidak mencantumkan jumlah kendaraan bermotor di Kota Padang pada tahun 2012 dikarenakan e-samsat baru terintegrasikan secara sempurna pada tahun 2013, sedangkan pada tahun 2012 belum dilakukan secara online, sehingga masing-masing daerah di Provinsi Sumatera Barat tidak terkoneksi langsung dengan kantor pusat.

3. Lokasi penelitian hanya dilakukan di Dinas Pengelolaan Keuangan Daerah Provinsi Sumatera Barat.

\section{DAFTAR RUJUKAN}

Erdiana, N., dan S. Sutopo. 2015. "Analisis Pengaruh Kualitas Produk, Kesadaran Merek, dan Harga Terhadap Keputusan Pembelian Mobil Honda Mobilio Di Kota Semarang", Fakultas Ekonomika dan Bisnis.

Istiyanto, B., dan L. Nugroho. 2017. "Analisis Pengaruh Brand Image, Harga, Dan Kualitas Produk Terhadap Keputusan Pembelian Mobil (Studi Kasus Mobil LCGC di Surakarta)". Eksis: Jurnal Riset Ekonomi dan Bisnis, Vol. 12, No. 1, hlm.

Kantale, N. J. 2016. "Analisis Potensi Dan Kontribusi Penerimaan Uptd Samsat Tomohon Terhadap Pendapatan Pajak Kendaraan Bermotor Dan Bea Balik Nama Kendaraan Bermotor Pada Provinsi Sulawesi Utara". Jurnal Berkala Ilmiah Efisiensi, Vol. 16, No. 4, hlm.

Male, G. C. 2015. "Analisis Kontribusi Pajak Mobil Tipe Low Cost Green Car Terhadap Penerimaan Pajak Kendaraan Bermotor di Sulawesi Selatan", Akuntansi, Universitas Hasanuddin, Makassar.

MediaIndustri. 2013. "LCGC (low cost green car)" http://www.kemenperin.go.id/download/4902. [diakses pada 12/09/2016].

Pratama, R. P. 2015. Kajian Tentang Pemilihan Moda Transportasi Untuk Perjalanan Kerja Masyarakat.

Rompis, N. E., V. Ilat, dan A. Wangkar. 2015. "Analisis Kontribusi Pajak Kendaraan Bermotor Terhadap Pendapatan Asli Daerah Provinsi Sulawesi Utara (Studi Kasus Pada Samsat Airmadidi)". Jurnal Berkala Ilmiah Efisiensi, Vol. 15, No. 4, hlm.

Sari, T. M. 2016. Analisis Kontribusi Pajak Kendaraan Bermotor dan Bea Balik Nama Kendaraan Bermotor terhadap Pendapatan Asli Daerah Provinsi Jawa Tengah (Studi Kasus Pada DPPAD Provinsi Jawa Tengah).

Sugiyono. 2016. Metode Penelitian Kuantitatif Kualitatif dan R\&D. Alfabeta. Bandung.

Sujarweni. 2015. SPSS Untuk Penelitian. Yogyakarta: Pustaka Baru Press.

Undang-Undang Nomor 23 Tahun 2014 Tentang Pemerintahan Daerah.

Winarso, W. 2015. "Analisis Penerimaan Pajak Kendaraan Bermotor Terhadap Pendapatan Asli Daerah (Studi Kasus Pada Kantor Cp Dispenda Provinsi Wilayah Kabupaten Sukabumi Ii)". SNIT 2015, Vol. 1, No. 1, hlm: 22-26.

Zuraida, I. 2013. Teknik Penyusunan Peraturan Daerah. Jakarta: Sinar Grafika. 